\title{
Detale projektowe jako jedna z przyczyn wad pierwotnych żelbetowych stropów w garażu wielostanowiskowym
}

\author{
Jerzy Szerafin, Anna Halicka \\ Katedra Konstrukcji Budowlanych, Wydziat Budownictwa i Architektury, Politechnika Lubelska, \\ e-mail:j.szerafin@pollub.pl, a.halicka@pollub.pl
}

Streszczenie: „Case study” przedstawia przypadek garażu wielokondygnacyjnego, w którym wkrótce po wykonaniu stwierdzono uszkodzenia płyt stropowych i zastoiska wody. Przyczyną obok niedostatecznej jakości betonu było błędne rozwiązanie spadków płyty stropowej oraz złe rozmieszczenie wpustów odprowadzających wodę.

Słowa kluczowe: garaż wielostanowiskowy, płyta stropowa, błędy projektowe.

\section{Wstęp}

Stropy garaży wielopoziomowych narażone są na oddziaływania trudnych warunków środowiskowych - podlegają wielokrotnym cyklom zamrażania i rozmrażania, często także w obecności chlorków nanoszonych na kołach samochodów, co oznacza klasę ekspozycji $\mathrm{XF} 4$, a co najmniej XF3. Stwarza to ostre wymagania dla samego betonu, takie jak wysoka klasa, minimalna zawartość cementu, czy też, niezbędna dla zapewnienia mrozoodporności, niska porowatość otwarta. Norma PN-EN 206-1 zaleca także napowietrzanie mieszanki betonowej oraz stosowanie kruszywa odpornego na zamrażanie/rozmrażanie. Ostre wymagania środowiska sprawiają także, że w projektowaniu należy bardzo starannie rozważyć tzw. ochronę konstrukcyjną, tzn. ograniczyć bezpośrednie oddziaływanie czynników środowiskowych (w tym wypadku okresowo zamarzającej wody) na konstrukcję. Duża liczba publikacji dotyczących awarii i uszkodzeń garaży wielopoziomowych w polskiej literaturze technicznej w ostatnich latach świadczy o tym, że zarówno projektanci jak i wykonawcy mają trudności w spełnieniu tych ostrych wymagań.

Przedmiotem niniejszego artykułu jest parking wielopoziomowy, w którym już po dwóch latach użytkowania wystąpiły uszkodzenia płyt stropowych. Jedną z ważnych przyczyn uszkodzeń były wady samego betonu stwierdzone w ekspertyzie [2]: zbyt niska klasa w stosunku do wymaganej C30/37 (na najniższym poziomie zaledwie C20/25), znaczna porowatość otwarta a także zastosowanie kruszywa zanieczyszczonego materiałami ilastymi.

Celem niniejszego artykułu jest jednak pokazanie przyczyn dodatkowych, leżących po stronie niezbyt starannego rozważania detali oraz akceptowanych przez projektantów, nie zawsze zasadnych, rozwiązań zamiennych (ekspertyza [1]).

Celem jest też uczulenie projektantów na konieczność starannego rozważania także mniej istotnych z pozoru zagadnień. 


\section{Opis konstrukcji obiektu}

Sześciokondygnacyjny garaż wielopoziomowy o pow. użytkowej $16583 \mathrm{~m}^{2}$ jest obiektem zbudowanym na planie prostokąta o wymiarach $86,95 \times 32,65 \mathrm{~m}$, z dwiema półkolistymi pochylniami - wjazdową i wyjazdową na osi podłużnej obiektu (Rys. 1).

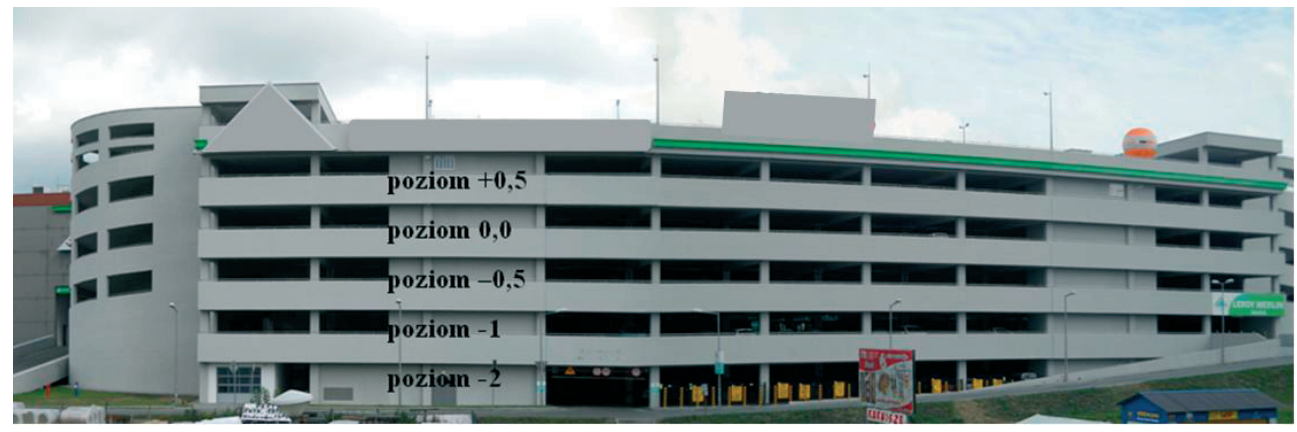

Rys. 1. Widok ogólny garażu z oznaczeniem poziomów kondygnacji

Konstrukcję budynku stanowi żelbetowy szkielet monolityczny. Słupy $60 \times 60 \mathrm{~cm}$ rozmieszczono na siatce prostokątnej o wymiarach: $7,85 \mathrm{~m} \mathrm{w}$ kierunku podłużnym oraz $12,07 \mathrm{~m}, 8,00 \mathrm{~m}$ i $11,32 \mathrm{~m} \mathrm{w}$ kierunku poprzecznym. Na słupach opierają się podciągi $60 \times 90 \mathrm{~cm}$, przebiegające poprzecznie. Płyty stropów oraz stropodachu ukształtowano od razu ze spadkami, a ich grubość zmienia się od $25 \mathrm{~cm}$ do $31 \mathrm{~cm}$. Na najniższym poziomie wykonano płytę betonową jako zamienną dla kostki brukowej przewidzianej pierwotnie w projekcie. Pochylnie wjazdowo-wyjazdowe wykonano jako płyty o grubości $25 \mathrm{~cm}$ oparte na żelbetowych ścianach. Dodatkowe usztywnienie budynku zapewniają żelbetowe ściany klatek schodowych. Konstrukcja garażu jest podzielona na 3 sekcje (z wyjątkiem stropodachu zdylatowanego na 5 sekcji).

\section{Zarysowania płyt stropowych}

W trakcie eksploatacji pojawiły się liczne zarysowania stropów pozwalające na penetrację betonu przez wodę:

1. Zarysowania dolnych powierzchni w postaci 2-3 rys w przęśle płyty, przebiegających równolegle do podciągów i grupujących się w centralnej części przęsła, o szerokości $0,1 \div 0,2 \mathrm{~mm}$ (w kilku przypadkach osiągają $0,3 \mathrm{~mm}$ ),

2. Zarysowania górnych powierzchni wzdłuż krawędzi podciągów i z reguły niedochodzące do linii słupów, o rozwartości $0,1 \div 0,6 \mathrm{~mm}$,

3. Zarysowania górnych powierzchni wychodzące z naroży płyty w miejscu połączenia z pochylniami, o szer. $0,3 \div 0,5 \mathrm{~mm}$, miejscami dochodzące do ok. $1 \mathrm{~mm}$ (Rys. 2),

4. Pojedyncze rysy prostopadłe do podciągów, o szerokości $0,05 \div 0,6 \mathrm{~mm}$, w niektórych przypadkach przelotowe, z reguły nie dłuższe niż rozpiętość przęsła płyty.

Zarysowania wymienione w punktach 1 i 2 powstały w wyniku odkształceń stropu pod obciążeniem ciężarem własnym i obciążeniem użytkowym pojazdów. Są one typowe dla płyt wieloprzęsłowych jednokierunkowo zbrojonych. Taki schemat statyczny założono w projekcie konstrukcyjnym, jednak rysy w strefie podporowej osiągnęły rozwartości więk- 
sze niż dopuszczalne. Może mieć na to wpływ znaczna grubość otuliny górnych prętów zbrojeniowych zwiększona przez ukształtowanie spadków.

Pęknięcia opisane w p. 3 pojawiają się w miejscach koncentracji naprężeń przy krawędzi ściany stanowiącej podporę stropu. Zarysowania opisane w p. 4 są wywołane przyczynami termiczno-skurczowymi.

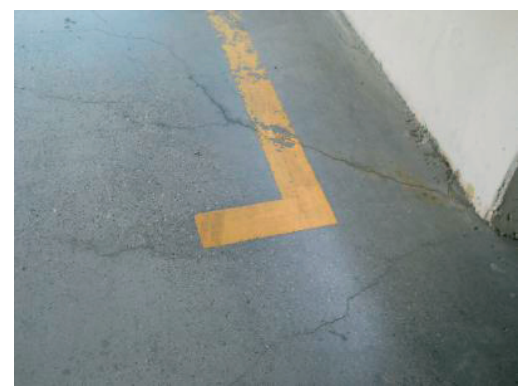

Rys. 2. Zarysowania górnej powierzchni płyty stropowej w miejscu połączenia z płytą pochylni wjazdowej

\section{Uszkodzenia powierzchni płyt stropowych}

Górne powierzchnie stropów międzykondygnacyjnych oraz płyty na gruncie wykazują miejscowe uszkodzenia w postaci złuszczeń i ubytków betonu o głębokości 2-3 cm. Największe uszkodzenia występują na najniższym poziomie i obejmują całą trasę od głównego wjazdu do pochylni wjazdowej. Uszkodzenia powierzchni betonu stropów są mniej rozległe i pojawiają się przede wszystkim w miejscach zastoisk wodnych, w strefach zwiększonego ruchu samochodów oraz przy wpustach stropowych (por. Rys. 3). Przy braku prac zabezpieczających zasięg uszkodzeń z roku na rok się powiększa.
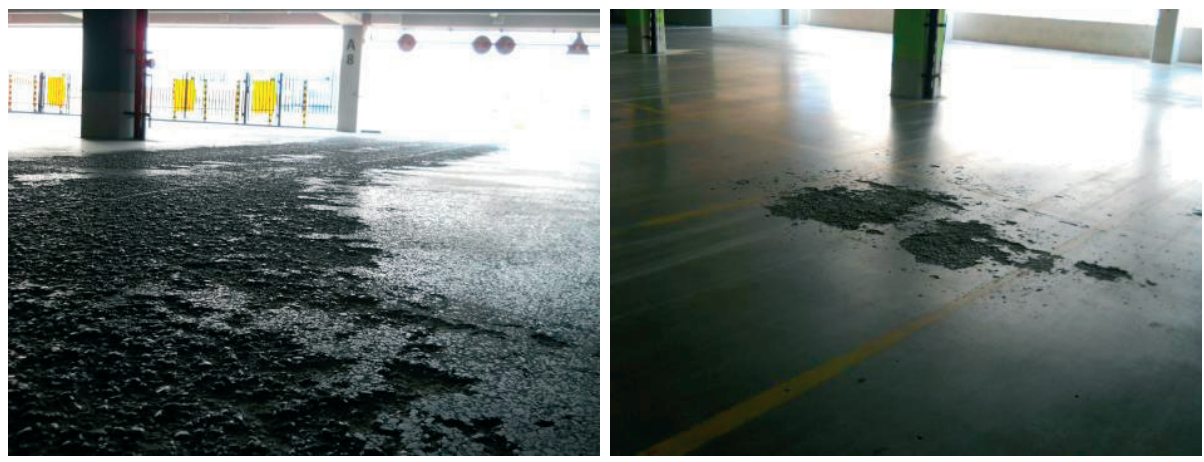

Rys. 3. Uszkodzenia powierzchni betonu: płyta na gruncie w strefie wjazdu na poz. -2 (z lewej), strop międzykondygnacyjny na poz. $-0,5$ (z prawej)

Uszkodzenia powierzchni wynikają z wbudowania betonu o zbyt niskich parametrach w stosunku do klasy ekspozycji, co opisano już w p.1. W otwarte pory betonu oraz jego drobne pęknięcia wnika woda nanoszona na kołach i maskach samochodów, podlegająca w okresie zimowym cyklom zamrażania i odmrażania. Największe zniszczenia strefy wjazdowej płyty na gruncie wynikają z jej największego obciążenia ruchem (przejeżdżają tamtędy wszystkie samochody). 


\section{Odprowadzenie wody opadowej}

Płyty stropowe wykonywano od razu ze spadkami, ukształtowanymi w celu odprowadzenia z powierzchni płyty wody deszczowej i topniejącego śniegu, nanoszonych przez pojazdy. Zaprojektowano nieduże wartości pochylenia w kierunku wpustów, w granicach $0,4 \div 0,6 \%$. Odwodnienie płyt stropowych miała zapewniać instalacja wyposażona we wpusty podłogowe.

Lokalizację wpustów zaprojektowano jednak niefortunnie (por. Rys. 4) - część z nich znajduje się w bezpośrednim sąsiedztwie podciągów. Tymczasem po rozszalowaniu stropów nastąpiło ugięcie elementów konstrukcji (płyty stropowej i podciągów), co częściowo zniwelowało spadki. Ugięcia stropów, pomierzone pod obciążeniem eksploatacyjnym, mieszczą się w przedziale $14,5 \div 27,5 \mathrm{~mm}$ i są mniejsze od wartości dopuszczalnej $a_{\text {lim }}=l_{\text {eff }} / 250=31 \mathrm{~mm}$, jednak okazały się wystarczająco duże dla zniwelowania i częściowo odwrócenia kierunku ukształtowanych spadków, a strefa podciągów okazała się lokalnym „wybrzuszeniem” stropu. W rezultacie w miejscach łatwych do przewidzenia powstały obszary bezodpływowe. Typowy przykład powstających zastoisk wodnych na powierzchni stropu międzypiętrowego pokazano na Rys. 4 i 5.

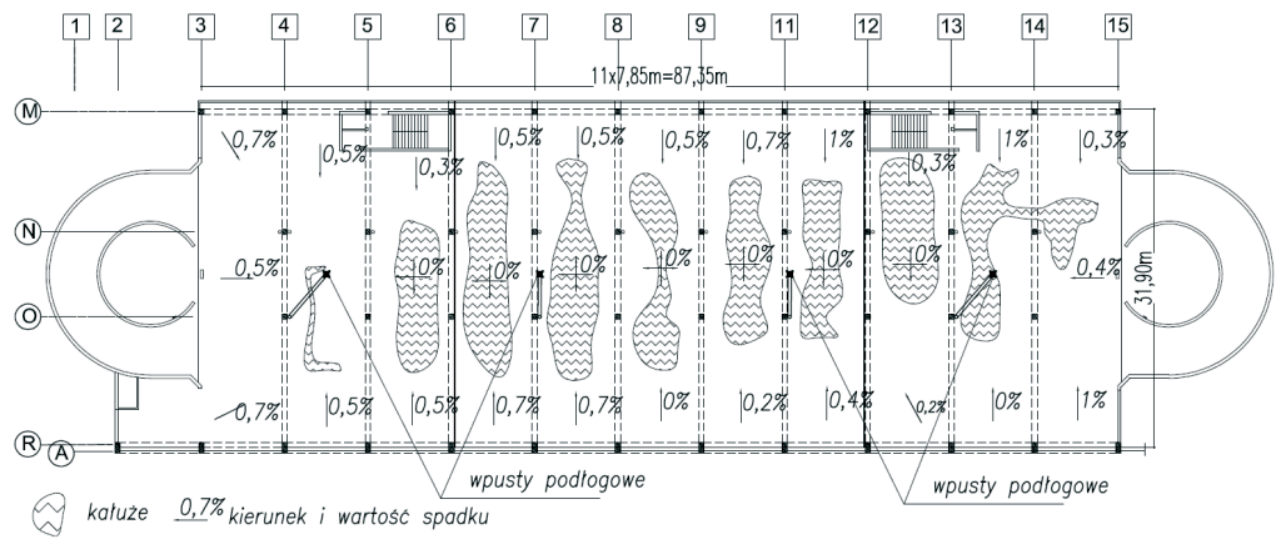

Rys. 4. Stefy bezodpływowe powstałe na powierzchni stropu

Pozostałe wpusty wprawdzie znalazły się w centralnej części płyty, ale - również wskutek ugięć - są w stanie odwodnić jedynie przylegający obszar stanowiący ok. 10\% odwadnianej powierzchni. Poprawne odprowadzenie wody ma miejsce jedynie w strefach skrajnych, gdzie nie ma istotnych ugięć płyty.

Opisana sytuacja świadczy o braku koordynacji między projektantem konstrukcji i instalacji - przy lepszej współpracy udałoby się umieścić odpływy w miejscach największych ugięć. Alternatywnym rozwiązaniem byłoby znaczne zwiększenie sztywności stropu, aby do minimum ograniczyć ugięcia.

Dodatkowo, już na etapie wykonawstwa część wpustów osadzono zbyt wysoko, w rezultacie kratka ściekowa wystaje ponad powierzchnię stropu.

Innym problemem związanym z odprowadzeniem wody są przecieki przez dylatację stropodachu wynikające z osadzenia uszczelki EPDM w zbyt głębokich bruzdach, w związku z czym napełniają się one wodą deszczową na głębokość ok $2 \mathrm{~cm}$, a także nieszczelności niezabezpieczonych dylatacji w stropach międzypiętrowych (Rys. 6). 


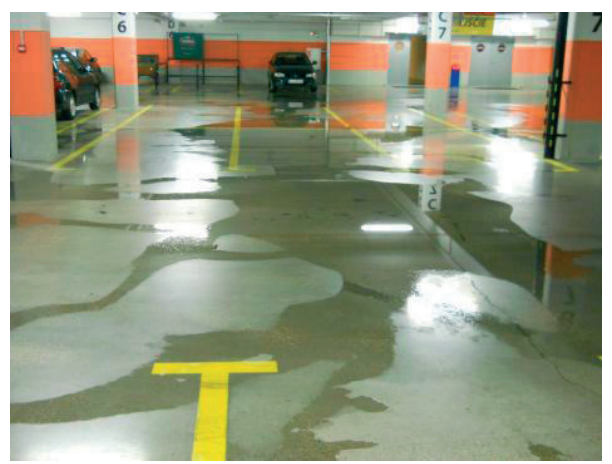

Rys. 5. Tworzące się kałuże na stropie poziomu $+0,5 \mathrm{w}$ trakcie przeprowadzania próby wodnej

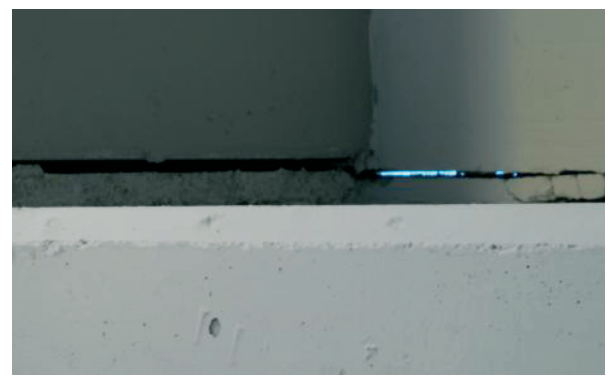

Rys. 6. Widok dylatacji stropu od dołu - widoczna niewypełniona szczelina dylatacyjna

\section{Izolacje i warstwy wykończeniowe stropów}

Pierwotnie zakładano w projekcie wykonanie na wszystkich płytach stropowych cienkowarstwowej elastycznej warstwy izolacyjnej, która miała chronić powierzchnię betonu przed bezpośrednim dostępem wody. Warstwa ta nakładana już po wystąpieniu zarysowań od ciężaru własnego stropu stanowiącego ok. $75 \%$ obciążenia całkowitego mostkowałaby też te pęknięcia.

W trakcie realizacji wykonano zaakceptowane przez projektanta rozwiązanie zamienne. Górna powierzchnia płyt stropowych oraz płyty na gruncie zostały wyszlifowane i nasączone impregnatem w celu zabezpieczenia przed wnikaniem wody. Rozwiązanie to należy uznać za nieprzemyślane - impregnacja nie daje efektu w postaci mostkowania rys. Ponadto zaimpregnowany beton jest śliski i w przypadku pojawienia się cienkiej warstwy lodu niebezpieczny dla użytkowników - zdarzały się przypadki urazów kończyn w wyniku upadków.

Na płytach pochylni wykonano mineralną warstwę antypoślizgową zawierającą kruszywo bazaltowe $\mathrm{z}$ wierzchnią warstwą poddaną wypłukiwaniu. Tu zaobserwowano niewielkie lokalne wykruszenia wierzchniej warstwy antypoślizgowej.

$\mathrm{Na}$ powierzchni stropodachu zostały wykonane systemowe warstwy izolacyjne z żywic epoksydowych uzupełnione warstwą zamykającą z żywicy poliuretanowej. Wykazują one pęknięcia w linii podciągów (szerokość od rys włosowatych do $0,5 \mathrm{~mm}$ ), złuszczenia cienkiej zamykającej warstwy poliuretanowej, lokalne odspojenia powłoki wraz z właściwą warstwą żywicy epoksydowej. 


\title{
7. Uwagi końcowe
}

Pomijając oczywiste błędy związane z wykonaniem wadliwego betonu oraz niezbyt fortunną zmianą w zakresie warstw izolacyjnych, istotną przyczyną wystąpienia uszkodzeń powierzchni betonu było gromadzenie się wody na stropie. Jest to efekt próby spełnienia trudnych do pogodzenia warunków: wykonania warstwy konstrukcyjnej spełniającej również funkcję warstwy spadkowej, a jednocześnie zaprojektowanej ekonomicznie, bez nadmiernego zbrojenia w celu wyeliminowania ugięć. Zabrakło jednak staranności przy projektowaniu spadków i koordynacji z projektantem projektującym instalację odprowadzenia wody.

Przykład wskazuje na konieczność szczególnie starannego wykonywania wszelkich izolacji i dylatacji oraz starannego rozważania odprowadzenia wody opadowej i kształtowania spadków w nawiązaniu do ugięć stropu.

\section{Literatura}

1. Szerafin J. Ekspertyza techniczna stropów żelbetowych w garażu wielopoziomowym. 2010.

2. Piasta W. Badania i właściwości fizycznych i mechanicznych betonu uległemu uszkodzeniu, który zostat pobrany z elementów wielopoziomowego parkingu. 2011.

3. PN-EN 206-1:2003 Beton. Część 1: Wymagania, właściwości, produkcja i zgodność.

\section{Design details recognized as the reasons of defects of reinforced concrete floors in the multi-storey garage}

\author{
Jerzy Szerafin, Anna Halicka
}

Department of Construction, Faculty of Civil Engineering and Architecture, Lublin University of Technology,e-mail: j.szerafin@pollub.pl, a.halicka@pollub.pl

\begin{abstract}
In the paper a 'case study' of a six-storey garage is described. Soon after the beginning of use the cracking and other damages of reinforced concrete floor slabs as well as stagnant pools of water on them were observed. The poor concrete, improper design solution regarding the slabs inclinations and distribution of pipes removing the rain water were recognized as causes of these damages.
\end{abstract}

Keywords: garage, floor slab, design errors. 